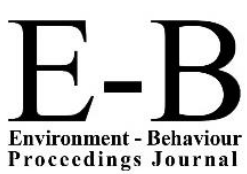

\title{
AicE-Bs2016Edinburgh
}

$7^{\text {th }}$ Asia-Pacific International Conference on Environment-Behaviour Studies, St Leonard Hall, Edinburgh University, United Kingdom,27-30 July 2016

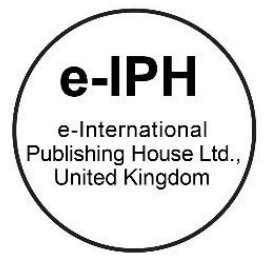

\section{Plagiarism: An Empirical Evidence of Business Students}

\author{
Syezreen Dalina Rusdi ${ }^{*}$, Norashikin Hussein²,Nor Azian Abdul Rahman³, Fauziah Noordin \\ University Teknologi Mara, Bandar Puncak Alam, 42300 Kuala Selangor, Selangor, Malaysia \\ ${ }^{4}$ Arshad Ayub Graduate Business School, Centre for Postgraduate \& Professional Studies, 40450 Shah Alam, Malaysia
}

\begin{abstract}
As the education world places countless emphasis on achievement and success, the issue of academic dishonesty particularly involving plagiarism has reached prevalent extents especially in the institutions of higher learning. Since this contemporary problem in higher education requires very urgent attention to curb, various factors were assessed for their influence on students' degree of plagiarism act. Therefore, this paper focuses on the extent of the business students' self-perceived plagiarism and factors contributing to the act. A total of 152 questionnaires were collected from final year students of four business degree programs in one of a public university in Malaysia. Findings revealed that negative attitude, followed by competence lacking were the major contributors of self-perceived plagiarism. Discussion and significance of the study are further discussed.

(C) 2016. The Authors. Published for AMER ABRA by e-International Publishing House, Ltd., UK. This is an open access article under the CC BYNC-ND license (http://creativecommons.org/licenses/by-nc-nd/4.0/).

Peer-review under responsibility of AMER (Association of Malaysian Environment-Behaviour Researchers), ABRA (Association of Behavioural Researchers on Asians) and CE-Bs (Centre for Environment-Behaviour Studies), Faculty of Architecture, Planning \& Surveying, Universiti Teknologi MARA, Malaysia..
\end{abstract}

Keywords:academic dishonesty, self-perceived plagiarism

\section{Introduction}

Universities are known to be the platform in shaping graduates to become not only highly skilled and technically competent, but also creating values, that target responsiveness, flexibility, motivation, attitudes and beliefs, as well as inculcating high standards of honesty and ethical responsibility in serving their relevant profession and society well (Liliana \& Florina, 2015; Brimble \& Stevenson-Clarke, 2005). Studying at a university in terms of process is a general term for education of the adult population, and includes all training activities implemented as regular university education, acquisition of a certain level of education or further education or lifelong learning (Klement,

\footnotetext{
* Corresponding author. Tel.: +6-013-363-5286

E-mail address:syezre5475@puncakalam.uitm.edu.my
}

2398-4287 @ 2016. The Authors. Published for AMER ABRA by e-International Publishing House, Ltd., UK. This is an open access article under the CC BY-NC-ND license (http://creativecommons.org/licenses/by-nc-nd/4.0/).

Peer-review under responsibility of AMER (Association of Malaysian Environment-Behaviour Researchers), ABRA (Association of Behavioural Researchers on Asians) and CE-Bs (Centre for Environment-Behaviour Studies), Faculty of Architecture, Planning \& Surveying, Universiti Teknologi MARA, Malaysia.

DOI: http://dx.doi.org/10.21834/e-bpj.v1i4.181 
2015). Yet, the irony of it in today's academic environment is the mounting case of academic dishonesty among students. One of the global matters related to academic dishonesty infecting many academic institutions is plagiarism. Plagiarism has become an epidemic and one of the most intense breaches of academic integrity because it undermines the principle that scholarly work will make an original and honest contribution to an existing body of knowledge (Bretag, 2013). In the context of this paper, the act of plagiarism is referred to as the wrongful appropriation and stealing of another author's language, thoughts, ideas or expressions and representation of them as one's own original work (Carroll, 2004) which is known to be equally serious ethical and moral dilemma for universities. The critical point to take into account is that the idea of academic misconduct and the reasons behind it varies across countries and differs according to academic levels (Rezanejad\&Rezaei, 2013). When students do not fully understand what constitutes such misconduct or what the penalties for its detection are, they may not see it as a problem even if they engage in the behavior (Smith et. al, 2007).

It is an unexpected fact that students in higher education are well aware of the wrong conducts of plagiarism, but despite this awareness, they engage themselves in such offensive behaviors by justifying these in the light of their own beliefs (Abida, Rabia\& Mohammed Bashir, 2013). Plagiarism is often associated with self-perception theory. Proposed by Daryl Bem (Bem,1967), this theory suggests that people develop attitudes and opinions by observing their own behavior and drawing conclusions from it.While it is true that behavior comes from people's inner personalities, Bem's insight was to suggest that the reverse also holds, in which persons' behavior is shaped by indirect pressures around them. Our behavior is always a product of how we see ourselves and the situations in which we are involved (Jiao \&Onwuegebuzie, 1999). In the issue of plagiarism, the perception of the subject matter itself has always been different among students. Not only the perception varies, causes that lead to plagiarism are also seen differently when viewed through different lenses. While the others aware that plagiarism is a big offense, some generally regard this act as 'no big deal'. Jones (2011) found that while all students recognized submitting an entire document written by another author as plagiarism, other students saw copying a limited amount of text as less serious. Colleen (2014) pointed out that students tend to think plagiarism only as copying work of others without proper citation. This contemporary problem in higher education requires very urgent attention to curb. To minimize its occurrence, it is important for academic institution to understand the causes of plagiarism.

As studies on academic dishonesty, plagiarism in particular, had focused much on business schools, it is noted that business students were generally more unethical and tolerant in their behavior and attitudes than non-business majors (Smyth \& Davis, 2004; Kisamore, Stone \&Jawahar, 2007). In the same line, it is crucial to find evidence on plagiarism activities among undergraduates especially involving business students as these students are future business leaders (Hadijah, Norashikin, Nusrah, Fauziah, \&Normala, 2012). The fact that existing literature deals almost exclusively with plagiarism in Western countries, the question arises whether this findings are true to Malaysia business students as well. This study is warranted due to the point that there is relatively very little research on the issue of plagiarism among students engaged in such unethical practices in Asian countries, especially Malaysia. Thus, this paper served to analyzing the students' level of self-perceived plagiarism as well as examining the factors contributing to plagiarism.

\section{Literature Review}

Previous research on this topic have investigated several reasons students engage in academic dishonesty such as poor academic standards, class sizes, increased competition for jobs, distance learning technologies and access to unlimited resources on the internet (Burton, Talpade, \& Haynes, 2011). Based on extensive interviews with master's degree students, factors of plagiarism activities evolved around two broad categories of internal and external contributing factors (Love \& Simmons, 1998). Two internal contributing factors were identified including personal attitudes and lack of competence while external factors involved accessibility to the internet and pressure such as time and task. (Caruana et al.,2000; Park, 2003; Scanlon \& Neumann, 2002).

\subsection{Internal factors of plagiarism}


According to Miller, Shoptaugh and Parkerson, (2008), the key of everything starts from the attitude. The increasing and decreasing level of cheating and plagiarism among business students are depending on the attitude of a person itself. Positive or negative attitudes and willingness to expend effort will be reflected in the incidence of plagiarism, since it may be seen as alternative to hard work (Smith, Ghazali\& Noor Minhad, 2007). Frequently attributable to desperation, often caused by procrastination or plain laziness forces students to resort to plagiarism because it seems easy for a student to paraphrase another author's ideas without appropriately crediting the source which supported the link between personal attitudes and self-plagiarism (Rezanejad\&Rezaie, 2013; Smith, et al., 2007). Plagiarism also constituted by poor time management skills and insufficient effort or desire for efficiency (Yeo, 2007; Jones, 2011). Similarly students considering academic dishonesty as no big deal since everyone else is doing it, and the idea that they can 'get away with it' are said to be the reasons for plagiarism (Jones 2011; Kwong, $\mathrm{Ng}$, Mark \& Wong, 2010 ). Therefore, it is hypothesized that:

H1: Negative attitude is significantly and positively related to self-perceived plagiarism.

As the education world places countless emphasis on achievement and success, lack of competence become a contributing factor in plagiarism in the pursuit of achieving higher grade point average (CGPA). Competency in English language for example, is essential for rephrasing, summarizing, and citing other individuals' work without resorting to cut and paste plagiarizing (Honig\&Bedi, 2012). At present, English is undoubtedly the dominant lingua franca (Bucur\&Popa, 2015). Lack of English proficiency particularly in a non-English speaking country, on top of a different cultural perspective of what constitute plagiarism and knowledge sharing, have been associated with higher levels of academic dishonesty (Ramzan, Munir, Siddique \& Asif, 2011; Cohen, 2004). They note that for students whose second language is English, even the act of paraphrasing is puzzling since their limited command of English would usually make it impossible for them to be critical or to raise their own opinions, let alone improving on the original wording (Zimmerman, 2012; Devlin \& Gray, 2007). As far as tertiary education is concerned, students are required to adhere to academic standards, including formalized referencing systems (Staggs, Kimmins\&Pavlovski, 2013). Lack of knowledge regarding correct ways of referencing, citing and paraphrasing information are also among factors contributing to plagiarism (Rosnow\&Rosnow, 1995; Staggs, Kimmins\&Pavlovski, 2013). Thus, it is hypothesized that:

H2: Lack of competence is significantly and positively related to self-perceived plagiarism.

\subsection{External factors of plagiarism}

Apart from the internal factors, external factors also come to play. In this era of technology, education has become more refined as the internet serves as a source of information and a means of communication, participation, collaboration and social networking, allowing students to be connected more than ever, which presents many benefits for learning by providing opportunities for students to work together and develop positive relationships (Walters \&Hunsicker-Walburn, 2015). It is true that today's generation have sophisticated skills in using digital technologies, but also that, through their exposure to these technologies, they have developed radically new cognitive capacities and learning styles (Prensky, 2001 cited in Onofrei\&lancu, 2015). However, it is important not to lose sight of the usefulness of the values which could now be emphasized in an optimal way in education through the new technologies (Onofrei\&lancu, 2015). With all the wonders and benefits of technology utilization in the teaching and learning process, challenges come ahead as it has made available a much wider number of webbased sources, facilitating the purchase or "cut-and-paste" of appropriate materials which encourage plagiarism (Sterngold, 2004). The predominance of electronic media in an information society has given rise to increasing incidence of plagiarism (Scanlon \& Neumann, 2002). Similarly, Khan and Balasubramanian (2012) found that the more technologically enabled, or digital, means of cheating was occurring nearly twice as often. The Internet has 
made it easy to locate relevant sources and to copy and paste together an entire section or chapter of a book or a thesis (Moten, 2014). This method of technology-facilitated plagiarism has become increasingly common due to effortless process of copying and pasting electronic text (Fish \&Hura, 2013). Therefore, it is hypothesized that:

\section{H3: Accessibility to the internet is significantly related to self- perceived plagiarism.}

The reality of a student's busy semester is that pressures increases as semester builds towards its end and that this pressure accumulates along with other environmental factors such as increasingly important assessments, encroaching examinations and tightening time deadline (Koh, Scully \&Woodliff, 2011). Consistent with this, time pressure and pressures students feel to achieve good grades is a frequently cited reason why students engage in plagiarism (Jones, 2011; Park 2003). In short, some students may take 'short cuts' option that is engaging in plagiarism to optimize their performance and to complete assessment as a consequence of time pressures especially among students who have a dispositional tendency toward competitiveness (Curtis \&Popal, 2011; Bennett, 2005; \& McCabe, Trevino, \& Butterfield, 2001). Ramzan, Siddique, Munir and Asif (2011) highlighted that most of the students plagiarize to get the right answers of their questions, ultimately to achieve high grades in their studies instead of getting expertise in their subjects of study. The desire to get good grades due to highly competitive environment has been reported as one of the primary motives to cheat (Chraif, 2015; McCabe, 2001; Rettinger\& Jordan, 2005). Apart from that, peer pressures also have a strong effect on students' perception of the act of plagiarism (Ellahi, Mushtaq\& Khan, 2013). Hence, it is hypothesized that:

H4: Pressure is significantly related to self-perceived plagiarism.

\section{Methodology}

A quantitative survey was undertaken to serve the purpose of this study. In one of a public university in Malaysia, self-administered questionnaires were distributed to a total of 152 final year students from four business degree programs. The questionnaires were divided into three sections. The first section of the questionnaire required respondents to rate the importance of 4 items to measure the level of self-perceived plagiarism. Instruments used in the study were from established sources and had proven to demonstrate high-reliability values. Instrument used to measure self-perceived plagiarism were adopted from Scanlon and Neumann (2002). The second section encompasses 15 items related to potential factors of plagiarism act adapted from Smith et al. (2007). All items were measured using five-point Likert scales ranged from 1 to 5 ( $1=$ strongly disagree to $5=$ strongly agree. Knowing the sensitive nature of the questions, all responses provided by the respondents were treated confidential and will be used for academic purpose only. The last part of the questionnaires involved collecting demographic information of the respondents, amongst are gender, age, semester of study, and course attended. All data were analyzed using Statistical Package for Social Sciences (SPSS).

\section{Findings}

A total of 160 sets of questionnaires were distributed to the final year students of four business degree programs of a public university in Malaysia. Out of 160 questionnaires distributed, only 152 were found to be usable for the study, yielding a response rate of 95 percent. Majority respondents were female of which represent 71.1 percent. Most of respondents have CGPA within the range of 3.00 to 3.49 .

In assessing students' level of self-perceived plagiarism, descriptive statistics as stipulated in Table 1 indicate the highest mean value of $3.70(S D=0.85)$ for accessibility to the internet followed by pressure $(\mu=3.57, S D=0.91$ ), lack of competence $(\mu=3.02, S D=0.86)$ and personal attitude $(\mu=2.51, S D=0.90)$. As for the extent of selfplagiarism, findings show the mean value of $2.94(S D=0.76)$. 
Table 1: Descriptive Analysis

\begin{tabular}{lcc}
\hline Variables & Mean & Standard Deviation \\
\hline Negative attitude & 2.51 & 0.90 \\
Accessibility to the Internet & 3.70 & 0.85 \\
Lack of competence & 3.02 & 0.86 \\
Pressure & 3.57 & 0.91 \\
Self-perceived plagiarism & 2.94 & 0.76 \\
Note: All items used a 5-point Likert scale with (1: strongly disagree and 5: strongly agree)
\end{tabular}

Correlation analysis was conducted to investigate the inter-correlations among variables. Based on Table 2, it shows that all independent variables (negative attitudes, accessibility to internet, lack of competence and pressure) have positive correlation with the dependent variable (self-perceived plagiarism). According to Cohen (1988), the correlation value of 0.5 and above is large, $0.3-0.49$ is moderate, and $0.1-0.29$ is small. The magnitude of the correlation for all the variable measures from $(r)=0.23$ to $(r)=0.56$.

Table 2: Correlation Analysis

\begin{tabular}{|c|c|c|c|c|c|}
\hline & Negative attitudes & $\begin{array}{l}\text { Accessibility to the } \\
\text { Internet }\end{array}$ & Lack of competence & Pressure & $\begin{array}{l}\text { Self-perceived } \\
\text { plagiarism }\end{array}$ \\
\hline Negative attitudes & 1.000 & & & & \\
\hline Accessibility to the Internet & $.35^{\star *}$ & 1.00 & & & \\
\hline Lack of competence & $.31^{* *}$ & $.34^{* *}$ & 1.00 & & \\
\hline Pressure & $.29^{* *}$ & $.56^{* *}$ & $.47^{* *}$ & 1.00 & \\
\hline Self-perceived plagiarism & $.37^{* *}$ & $.23^{* *}$ & $.35^{\star *}$ & $.26^{* *}$ & 1.00 \\
\hline
\end{tabular}

${ }^{* *}$ Correlational significant at the 0.01 level (2-tailed)

In investigating the relationship between independent variables (negative attitudes, accessibility to internet, lack of competence and pressure) and dependent variable (self-perceived plagiarism), linear multiple regression model was used. Based on results in Table 3, only negative attitude and lack of competence were found to be significant with self-perceived plagiarism. The $\mathrm{R}^{2}$ for the model above is 0.20 . Meanwhile, the adjusted $\mathrm{R}^{2}$ is 0.18 . Therefore, the variance of the model which consisted of independent variables (negative attitude, accessibility to the internet, lack of competence and pressure) contribute on students self-perceived plagiarism is 20 percent and another 80 percent may be contributed by the other factors. Findings indicate that negative attitude has the most significant contribution on students self-perceived plagiarism $(\beta=0.277, p<0.01)$. Hence, the more of negative attitude they possessed, the more likely they are to be involved in self-perceived plagiarism. Therefore, $\mathrm{H} 1$ is supported. The second unique contribution is lack of competence $(\beta=0.223, p<0.01)$. This explains that limited competency among 
students lead to higher self-perceived plagiarism. Therefore, $\mathrm{H} 3$ is supported. It is also reported that accessibility to internet and pressure have no significant influence on self-perceived plagiarism.

Table 3: Multiple Regression Analysis

\begin{tabular}{|c|c|c|}
\hline & Self-perceived plagiarism & Significance \\
\hline \multicolumn{3}{|l|}{ Independent variables } \\
\hline Negative attitude & $0.277^{\star *}$ & 0.001 \\
\hline Accessibility to the Internet & 0.026 & 0.776 \\
\hline Lack of competence & $0.223^{*}$ & 0.010 \\
\hline Pressure & $0.061^{*}$ & 0.525 \\
\hline$F$ value & 9.349 & \\
\hline $\mathrm{R}^{2}$ & 0.20 & \\
\hline Adjusted R2 & 0.18 & \\
\hline
\end{tabular}

\section{Discussion and Recommendation}

This study aims to analyze the students' level of self-perceived plagiarism and examine the factors that lead to the self-perceived plagiarism. From the findings, negative attitude was found to have the greatest relevance as a cause of self-perceived plagiarism. Results show that negative attitude has the most significant relationship with selfperceived plagiarism. Similarly Razera, Verhagen, Pargman and Ramberg (2010) found that lack of motivation forced students towards plagiarism. A poor time management by students and the habit of procrastination lead students to consider plagiarism as easy way out (Comas \& Sureda, 2010). In accordance with Chapman and Lupton (2004), students are aware of the unethical act but still they continue to cheat as they believed that the gain is greater. Another contributing factor of self-plagiarism is lack of competence among students. This is supported by Pennington (2010) and Rezera et al. (2010) that without formal training, students would be lacking or have no skills in synthesizing ideas, writing reports substantiated with multiple sources, referencing style, and not being well-verse in academic writing convention. These students have no choice but to utilize whatever little knowledge they have to complete the assignment, and they might unintentionally be involved in plagiarizing works they refer to in doing the assignment (Habsah \& Maimunah, 2013). At the same page, as students face fierce competition to achieve high grades, most of them plagiarise to get the right answers of their questions instead of getting expertise in their subjects of study (Ramzan et al., 2011). These results are in accordance to Jones (2011), as he reveals that the top three reasons students engage in academic dishonesty which were grades $(92 \%)$, procrastination (83\%), and too busy which lead to not enough time to complete assignment or study for test $(75 \%)$. This study suggested also suggested that pressure has no significance contribution to self-perceived plagiarism. In consistent with Koh, Scully and Woodciff (2011), large percentage of students will plagiarize whilst under no perceived pressure. It is believed that pressure is more associated to cheating behaviour rather than plagiarism. This is supported by previous research that pressure to do well, task and time pressure force students to cheat (Chiesl, 2007). In regard of accessibility to internet, it is reported that there is no significant contribution to self-perceived plagiarism. According to Comas and Sureda (2010), students tend to focus on lecturers, teaching styles and the type of task as the main reasons why university students commit academic plagiarism, rather than personal behaviour or the development of the ICT as developments in ICT have made it easier to detect this practice of academic dishonesty.

On the basis of this study, it can be suggested that the two core reasons for plagiarism were negative attitude and lack of competence. For the issue of negative attitude like motivation, procrastination and poor management of time, faculty at all levels must take the initiative in changing the attitude of students. This attitude problem can be minimized by self-motivation and time management programs (Day, 2008).It is suggested that one of the way to reduce it, is by increasing supervision. Students need to be supervised more stern and being observed consistently to ensure that they did not get the chance or have the intention to plagiarized (Miller et al.,2008) As for lack of competence, it is strongly recommended to organize boot camps, seminars, workshops and conferences to educate 
students on their writing skills including citation and referencing, fair publishing, proficiency in English language as well as the plagiarism issue, its consequences, and tools and techniques to minimize or avoid plagiarism all together (Emandi, 2015; Ramzan et al., 2011). Preparing yourself and make yourself equipped with enough knowledge will prevent one from committing the academic crime. In the context of education sector especially in higher learning institutions, a standardize policy regarding plagiarism and its possible penalties should be provided (Koh et al., 2011). To conclude, this study would be an eye opener for the Ministry of Education in Malaysia, higher education institutions, and community as a whole. Even so, results of this study could not be used to generalize to other population as students from other programs in other faculties might have different perceptions self-perceived plagiarism. The results of this study propose further directions for extensive research in future in which robust analysis could be done across faculties or universities as a larger sample to explore the extent of plagiarism activities in Malaysia.

\section{Acknowledgements}

The authors would like gratefully research support under the Research Acculturation Grant Scheme (RAGS) administered by UniversitiTeknologi Mara and funded by the Malaysian Government.

\section{References}

Bem, D.J. (1967). Self-perception: An alternative interpretation of cognitive dissonance phenomena. Psychological Review, 74(3), 183-200.

Bennett, R. (2005). Factors associated with student plagiarism in a post-1992 university. Assessment \&Evaluation in Higher Education, 30, 137162.

Bretag ,T. (2013). Challenges in Addressing Plagiarism in Education. PLoS Med 10(12): e1001574.doi:10.1371/journal.pmed.1001574

Brimble, M., \& Stevenson-Clarke, P. (2005).Perceptions of the prevalence and seriousness of academic dishonesty in Australian Universities, The Australia Educational Researcher, 32(3), 19-44.

Brown, B.S., Weible, R.J. \& Olmosk, K.E. (2010). Business school deans on student academic dishonesty: A survey. College Student Journal, 44(14), 229-309

Bucur,N. \& Popa, O. (2015). The Evolution of the English Subject Curriculum in Romanian Primary and Lower Secondary Education. Procedia Social and Behavioral Sciences, 203, 50 - 56

Burton, J. H., Talpade, S., Haynes, J. (2011). Religiosity and test-taking ethics among Business School Students. Journal of Academic and Business Ethics. 4, 1-8.

Caruana, A., Ramaseshan, B. \& Ewing, M.T. (2000). The effect of anomie on academic dishonesty among university students, The International Journal of Education Management, 14 (1), 23-30.

Chapman, K. J., \& Lupton, R. A. (2004). Academic dishonesty in a global educational market: A comparison of Hong Kong and American university business students. International Journal of Educational Management, 18(7), 425-435.

Chiesl, N,(2007) Pragmatic Methods to Reduce Dishonesty in Web-based Courses. The Quarterly Review of Distance Education, 8(3), 203211 
Chraif, M., (2015). Correlative Study between Academic Satisfaction, Workload and Level of Academic Stress at 3rd Grade Students at Psychology. Procedia - Social and Behavioral Sciences, 203, 419 - 424

Cohen, J. (2004). Addressing inadvertent plagiarism: A practical strategy to help non English speaking background (NESB) students. In H. Marsden, M. Hicks, \& A. Bundy (Eds.), Educational integrity: Plagiarism and other perplexities, Proceedings of the First Australasian Educational Integrity Conference: 26-32. Adelaide, South Australia:

Cohen, J. (1988). Statistical power analysis for behavioural sciences (2nd Ed.). New Jersey: Lawrence Erlbaum

Comas-Forgas, R., \& Sureda-Negre, J. (2010). Academic plagiarism: Explanatory factors from students' perspective. Journal of Academic Ethics, $8(3), 217-232$.

Curtis, G. J., \& Popal, R. (2011). An examination of factors related to plagiarism and a five-year follow up of plagiarism at an Australian university. International Journal for Educational Integrity 7(1), 30-42.

Day, K. (2008), Time is not on our side, in Howard, R.M. and Robillard, A.E. (Eds), Pluralizing Plagiarism: Identities, Contexts, Pedagogies, Boynton/Cook Publishers, Portsmouth, $\mathrm{NH}$.

Devlin, M. \& Gray, K. (2007). In their own words: a qualitative study of the reasons Australian students plagiarize. Higher Education Research \& Development, 26(2), 181-98.

Ellahi, A., Mushtaq, R. \& Khan, M.B. (2013) Multi campus investigation of academic dishonesty in higher education of Pakistan. International Journal of Educational Management, 27(6), $647-666$.

Emandi, E. (2015). English Workshops for Primary School Children in Romania - A Privileged Didactic Activity. Procedia - Social and Behavioral Sciences, 203, $147-152$.

Honig, B. \& Bedi, A. (2012). The Fox in the Hen House: A Critical Examination of Plagiarism Among Members of the Academy of Management University of South Australia. Academy of Management Learning \&Education, 11(1), 101-123.

Habsah, H. \& Maimunah, I. (2013). Plagiarism: More than Meets the Eye. Advances in Language and Literary Studies. 4 (2), 147-151

Hadijah, I., Nurashikin, H., Nusrah, S., Fauziah, N., \& Normala, D., (2012), Academicdishonesty: Why business students participate in these practices?, Procedia Sosial and Behavioral Sciences.

Jiao, Q. G. \& Onwuegbuzie, A. J.(1999). Self-perception and library anxiety: an empirical study, Library Review, 48(3), 140 - 147.

Jones, D. R. L. (2011). Academic Dishonesty: Are more students cheating? Business Communication Quarterly. 74, 141-150.

Khan, Z.R. \& Balasubramanian, S. (2012). Students go click, flick and cheat, e-cheating, technologies and more, of Academic and Business Ethics, 6, 1-26.

Klement, M. (2015). How to Educate University Students: Analysis of Students` Attitudes to Forms, Methods, and Tools Applied within the Process of Education. Procedia - Social and Behavioral Sciences, 203, 134-140

Koh, H.P., Scully, G. \& Woodliff, D.R. (2011). The impact of cumulative pressure on accounting students' propensity to commit plagiarism: an experimental approach. Accounting and Finance, 51, 985-1005 
Kwong, T., Ng, H.M, Mark, K.P., \& Wong, E. (2010), Students' and faculty's perception of academicintegrity in Hong Kong, Campus-Wide Information Systems, 27(50), $341-355$.

Liliana,D. \& Florina, P.S. (2015) Education, Knowledge and Innovation from a Mechatronics Perspective. Procedia-Behavioral Science, 203, 205209.

Love, P.G. \& Simmons, J. (1998). Factors influencing cheating and plagiarism among graduate students in a college of education. College Student Journal, 32(4), 1-8.

McCabe, D. L. (2001). Cheating: Why students do it and how we can help them stop. American Educator, 25, 38-43.

McCabe, D. L., Trevino, L. K., \& Butterfield, K. D. (2001). Cheating in academic institutions: A decade of research. Ethics and Behavior, 11, 219232

Miller, A., Shoptaugh, C., \& Parkerson, A. (2008). Under Reporting Of Cheating In Research Using Volunteer College Students. College Student Journal, 42(2), 326-339.

Onofrei, S.G., \& lancu, L. (2015). The Role of New Technology in Teaching through Proverbs in Primary School. Procedia - Social and Behavioral Sciences, 203, $130-133$

Park, C. (2003). In other (people's) words: plagiarism by university students - literature and lessons. Assessment and Evaluation in Higher Education, 28(5), 471-88.

Ramzan. M., Munir, M.A., Siddique, N., \& Asif, M. (2012). Awareness about plagiarism amongst university students in Pakistan, Journal of higher education, 64(1), 73-84.

Razera, D., Verhagen, H., Pargman, T. C., \& Ramberg, R. (2010). Plagiarism awareness, perception, and attitudes among students and teachers in Swedish higher education-a case study. Paper Presented at the 4th International Plagiarism Conference-Towards an authentic future.

Rosnow, R.L. \& Rosnow, M. (1995), Writing Papers In Psychology (3rd ed.), Brooks/Cole, Pacific Grove, CA.

Rettinger, D. A., \& Jordan, A. E. (2005). The relations among religion, motivation, and college cheating: A natural experiment. Ethics and Behavior, 15, 107-129

Rezanejad,A., \& Rezaei, S. (2013). Academic Dishonesty at Universities: The Case of Plagiarism Among Iranian Language Students. J Acad Ethics, 11,275-295

Scanlon, P.M. \& Neumann, D.R. (2002). Internet plagiarism among college students, Journal of College Student Development, 43, 374-85.

Singh, P., Abdul Ghani, P., \& Teoh, S.H., (2009). Quantitative data analysis for novice researchers. Malaysia:Primera Publishing.

Smith, M., Ghazali, N., \& Noor Minhad, S.F. (2007). Attitudes towards plagiarism among undergraduate ccounting students: Malaysian evidence. Asian Review of Accounting, 15(2), $122-146$.

Stagg, A., Kimmins, L., \& Pavlovski, N. (2013). Academic Style with Substance, The Electronic Library, 31(4), 452 - 464

Sterngold, A. (2004). Confronting plagiarism: How Conventional Teaching Invites Cyber Cheating. 16-21. 
Rusdi, S.D., et.al. / $7^{\text {th }}$ AicE-Bs2016Edinburgh, UK, 27-30 July 2016 / E-BPJ, 1 (4), September 2016 (Pp.62-71)

Walters, A.A., \& Hunsicker-Walburn, M.J. (2015). Exploring perceptions of technology's impact on academic misconduct, Journal of Applied Research in Higher Education, 7(1), 32- 42

Yeo, S. (2007), First-year university science and engineering students' understanding of plagiarism. Higher Education Research \& Development, 26(2), 199-216.

Zimerman, M. (2012). Plagiarism and international students in academic libraries. New Library World, 113(5/6). 290 - 299 